\title{
A new intersectional hybrid in the genus Potentilla (Rosaceae) from Northern Mongolia
}

\author{
V. Gundegmaa ${ }^{1}$, A. A. Kechaykin ${ }^{2}$ \\ ${ }^{1}$ Deparment of Biology, School of Mathematics and Natural Sciences, Mongolian National University of Education, \\ Baga Toiruu-14, Ulaanbaatar,21064898,Mongolia.E-mail: chalhorum@gmail.com \\ ${ }^{2}$ South-Siberian Botanical Garden, Altai State University, Lenina pr. 61, Barnaul, 656049, Russia. \\ E-mail: alekseikechaikin@mail.ru
}

Keywords: Altai, Arkhangai aimag, Khangai, Mongolia, nothospecies nova, Potentilla $\times$ vanzhilii, Tarbagatai Range.

Summary. Potentilla $\times$ vanzhilii is described as a new intersectional hybridogenous species found in Northern Mongolia. The plant has been gathered twice in the north-eastern part of the Tarbagatai Range, Central Khangai (Khangai botanical-geographical region of Mongolia). Potentilla nivea (sect. Niveae) and P. multifida (sect. Multifidae) are supposed to be parental species for $P . \times$ vanzhilii. Besides, $P$. altaica, P. rhipidophylla, and P. tuvinica are found to be related to $P . \times$ vanzhilii. The features that distinguish these closely related species from $P . \times$ vanzhilii are indumentum and the morphology of leaf blades and generative organs. The distribution area, ecology and illustrations of the new nothospecies are provided, and its stability is proved. Determination key for $P$. $\times$ vanzhilii and related species is also given.

\section{Новый межсекционный гибрид в роде Potentilla (Rosaceae) из Северной Монголии}

\author{
В. Гундегмаа ${ }^{1}$ А. А. Кечайкин ${ }^{2}$ \\ ${ }^{1}$ Кафедра биологии, факультет математики и естественных наук, Монгольский национальный университет \\ образования, Бага Тоируу-14, г. Улан-Батор, 21064898, Монголия \\ ${ }^{2}$ Южно-Сибирский ботанический сад, Алтайский государственный университет, \\ пр. Ленина, 61, г. Барнаул, 656049, Россия
}

Ключевые слова: Алтай, Архангайский аймак, Монголия, новый нотовид, Хангай, хребет Тарбагатай, Роtеntilla $\times$ vanzhilii.

Aннотация. Potentilla $\times$ vanzhilii описывается как новый межсекционный гибридогенный вид, обнаруженный в Северной Монголии. Растение было дважды собрано в северо-восточной части хребта Тарбагатай в Центральном Хангае (Хангайский ботанико-географический район Монголии). Предполагаемыми родительскими видами $P . \times$ vanzhilii являются P. nivea из секции Niveae и P. multifida из секции Multifidae. Выявлено, что, кроме родительских видов, близкими к $P$. $\times$ vanzhilii являются также P. altaica, P. rhipidophylla и $P$. tuvinica. От $P$. $\times$ vanzhilii близкие виды отличаются особенностью опушения, морфологией листовых пластинок и генеративных органов. Охарактеризована область распространения и экология, приведено изображение нового гибридогенного вида; доказана его стабильность. Составлен ключ для определения $P$. $\times$ vanzhilii и родственных видов. 


\section{Introduction}

During the field study on the territory of Northern Mongolia in 2016, the scientists from the Mongolian National University of Education discovered an interesting population of plants from the genus Potentilla. Some individuals from this population distinctly differed from other Potentilla species of the Mongolian flora. The revision of herbarium materials from UBA (Biological Institute, Academy of Sciences of the Mongolian People's Republic, Ulaanbataar) revealed a specimen collected in 1976, whose morphological features were identical to those of the species found in 2016. This specimen differed from our plants by greater height of the stems only (30-40 cm in contrast to $10-25 \mathrm{~cm}$ for our plants). All the specimens of this interesting Potentilla species were gathered in the north-eastern part of the Tarbagatai Range situated in the center of the Khangai Mountains. This territory belongs to Tariat somon of Arkhangai aimak and corresponds to the Khangai botanical-geographical region according to V. I. Grubov (1982). The study of materials on the genus Potentilla in herbaria of Russia (ALTB, IRK, LE, MW, NS, and NSK) and Europe (HAL, HEID, OSBU, and PR), which contain large collections on the Mongolian flora, did not reveal specimens with this morphology. We noted that the specimens of the discovered Potentilla grew in the same population as $P$. nivea $\mathrm{L}$., nom. cons. prop. and $P$. multifida L. and combined the morphological features of both species. Therefore, we suggest that the above-mentioned specimens represent a newly discovered taxon of hybridogenous origin which we describe herein as $P . \times$ vanzhilii V. Gundegmaa et Kechaykin, nothosp. nov. The study of the herbarium materials and determination keys of the Asian Potentilla species (Soják, 2012), enabled us to identify three species closely related to $P . \times$ vanzhilii. Similar to the supposed parental species ( $P$. nivea and P. multifida), these species differ from the new taxon by the nature of indumentum and the morphology of leaf blades and generative organs. The description, illustration and affinity of $P . \times$ vanzhilii are given below. The paper also provides the image of the paratype of $P$. rhipidophylla Soják, the species closely related to the new taxon, and the determination key for related species.

\section{Taxonomic treatment}

Potentilla $\times$ vanzhilii V. Gundegmaa et Kechaykin, nothosp. nov.; $P$. nivea L., nom. cons. prop. $\times$ P. multifida L. (Fig. 1).
Type: "Arkhangai aimak, Tariat somon, the right bank of the Khunzhiliin gol river (source) $1 \mathrm{~km}$ to the north of the Khadat spring near the border with Khubsugul aimak, on the edge of the sparse forest. N48.2220, E99.5410, 2046 m a. s. 1. 20 VI 2016. V. Gundegmaa" (UBA; iso - ALTB, UBA).

Paratype: "Arkhangai aimak, Tariat somon, Tarbagatai Range, near the Khadat spring, meadows of the river valley, dry river bed. 31 VII 1976. E. Ganbold" (UBA!).

\section{Description of the new taxon}

Perennial plant $10-40 \mathrm{~cm}$ high. Caudex simple, covered with dark-brown remains of decayed stipules. Stems 2-7, ascending at base, rarely erect, sometimes curved along the entire length. Basal leaves ternate, $2-7 \mathrm{~cm}$ long. Leaflets $0.8-2 \mathrm{~cm}$ long and $0.5-0.7 \mathrm{~cm}$ wide, sessile, sometimes the terminal leaflet with a short petiole $1-2 \mathrm{~mm}$ long. Leaflets pinnately dissected to $2 / 3$ or even to midrib into 3-5(6) almost linear pointed segments at each side. Lower leaflet surface covered with whitish or grayish tomentum mixed with short crispate hairs, upper surface covered with sparse short curved appressed and semi-appressed hairs. Cauline leaves similar in morphology to basal ones, not numerous, $1-2(3), 1-3 \mathrm{~cm}$ long with short petioles. Leaf petioles very thin, covered with crowded short crispate hairs $0.5-0.8 \mathrm{~mm}$ long and single curved hairs up to 0.8 $\mathrm{mm}$ long (rarely curved hairs absent). Stipules with entire acute auricles, the outer side covered with sparse grayish tomentum mixed with short crispate hairs, the inner side glabrous. Inflorescence typically multiflorous. Flowers small, $0.8-1 \mathrm{~cm}$ in diameter. Calyx densely covered with short crispate and longer curved appressed hairs. Sepals (calyx segments) narrow-triangular, acute, 3-4 mm long, equal to or slightly higher than lanceolate episepals (epicalyx segments). Petals obovate, with a small mucro in the upper part, light yellow, typically up to $4 \mathrm{~mm}$ long, slightly exceeding the calyx. Styles thin, short, typically curved, $0.6-0.7 \mathrm{~mm}$ long, identical along the entire length, with slightly widened stigma in the upper part, sometimes with slightly widened base. Mature nutlets (achenes) light green, typically $1 \mathrm{~mm}$ long, with small (narrow and shallow) wrinkles. Stamens 20, arranged in two whorls, the outer whorl of stamens with short anther filaments, the inner whorl of stamens with long anther filaments. No glandular indument, or occasional glandules observed on stems, leaf petioles and stipules.

Distribution area. Potentilla $\times$ vanzhilii was discovered in two closely situated localities in the 


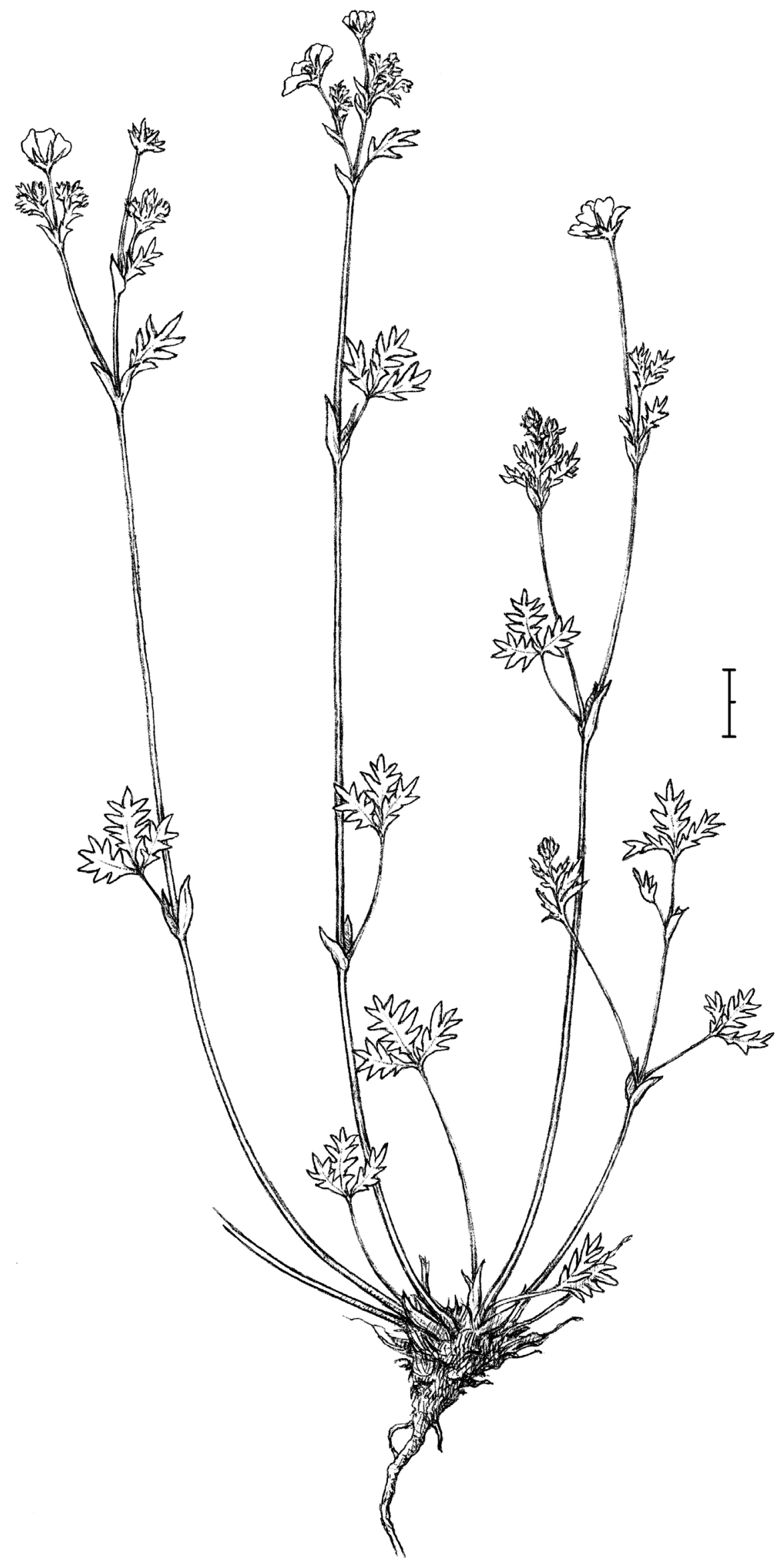

Fig. 1. Potentilla $\times$ vanzhilii, nothosp. nov. Scale bar: $1 \mathrm{~cm}$. Drawn by K. Shcherbinin based on type material. 


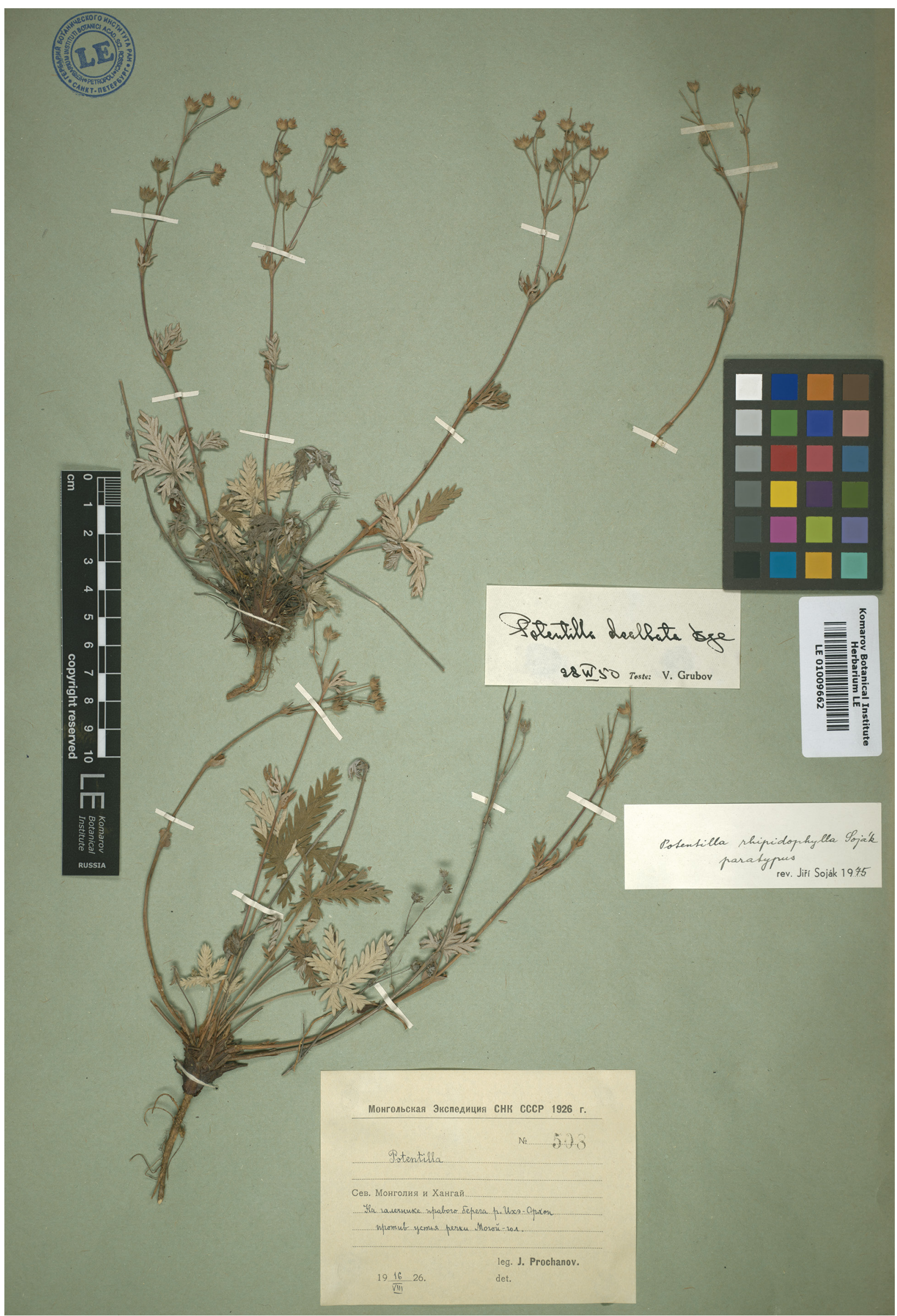

Fig. 2. Typical specimen of Potentilla rhipidophylla (LE10009662). 
north-eastern part of the Tarbagatai Range in the central Khangai (Tariat somon, Arkhangai aimak, on the border with Khubsugul aimak). No other collections of the nothospecies are currently known.

Ecology. Potentilla $\times$ vanzhilii belongs to the mesophytic group of Potentilla. It grows on pebbles and open stony slopes in valleys of small rivers, among bushes near hemlock forests.

Etymology. The hybridogenous species is named after Vanjil Choijinjav, the father of the first author of the present paper, in token of the gratitude for assistance in the organization of many fieldworks on the territory of Mongolia and for direct participation in Potentilla gathering.

Affinity. The described hybridogenous species is assumed to have originated through hybridization between $P$. nivea and P. multifida. Unlike $P$. nivea, $P . \times$ vanzhilii does not have a flaky tomentum on petioles of leaves and stalks; it has smaller petals (4-5 $\mathrm{mm}$ in contrast to 7-9 $\mathrm{mm}$ for $P$. nivea) and styles of the same width along the entire length or slightly widened at base (not clearly widened at base with expressed papillose tubercles). Additionally, in contrast to $P$. nivea, the described taxon has deeply pinnatifid leaves (dissected to $2 / 3$ or even to midrib unlike those dissected to $1 / 3$ for $P$. nivea). The features that distinguish the described taxon from P. multifida are indumentum (stalks and petioles are covered with crispate and curved hairs as well as very short straight appressed hairs), leaf blades (leaves are ternate rather than pinnate), and wrinkled vs. smooth nutlets (achenes). In addition to the supposed parental species, three more Potentilla species are related to $P . \times$ vanzhilii. One of them is $P$. rhipidophylla. This species is described from the Khangai region and, in Sojak's opinion, it is a hybridogenous taxon originated through hybridization between $P$. crebridens Juz. and P. multifida (Soják, 1986). The taxon differs from P. $\times$ vanzhilii by digitate (or palmate) leaves (not ternate), longer hairs that cover stalks and petioles (1-1.5 $\mathrm{mm}$ on average unlike $0.5-0.8 \mathrm{~mm})$, larger leaflets $(1.3-3(4) \times 0.6-1.2 \mathrm{~cm}$ in contrast to $0.8-2 \times$ $0.5-0.7 \mathrm{~cm})$ that are dissected into more numerous segments (on average, 5-9 segments at each side unlike 3-5 segments). A scanned image of one of the $P$. rhipidophylla paratypes is given for visual comparison (Fig. 2). The other species related to $P$. $\times$ vanzhilii is $P$. altaica Bunge originated purportedly through hybridization between $P$. arenosa (Turcz.) Juz. and P. multifida (Peschkova, 1979; Soják, 1986, 2009). This species is characterized by several features distinguishing it from $P . \times$ vanzhilii. Petioles are covered with straight bristly semi-appressed or horizontally arranged leaves up to $1.2 \mathrm{~mm}$ long mixed with very short curved (not crispate) hairs. Potentilla altaica has a root rosette formed by a mix of digitate leaves comprising three, four, or five leaflets (unlike $P . \times$ vanzhilii with only ternate leaves). Leaflets of P. altaica are always dissected nearly to midrib (unlike prevailing $2 / 3$ for $P$. $\times$ vanzhilii). Beneath along veins, $P$. altaica leaflets are covered with numerous straight appressed hairs up to $1 \mathrm{~mm}$ long that often form a silky indumentum $(P . \times$ vanzhilii does not have such hairs). Styles of $P$. altaica exhibit a widened base with large expressed papillose tubercles (style base in $P . \times$ vanzhilii is widened only slightly and has no papillose formations). The last taxon close to P. $\times$ vanzhilii is $P$. tuvinica Artemov, which originated through hybridization between $P$. evestita Th. Wolf and P. multifida (Artemov, 2005). This taxon is distinguished from newly described hybridogenous species by styles with relatively small papillose tubercles observed at the base. Petioles of $P$. tuvinica are covered with long (ca. $1 \mathrm{~mm}$ long) semi-appressed and patent, straight or curved (though not crispate) hairs. Stems of $P$. tuvinica are almost glabrous or covered with sparse appressed or relatively straight semiappressed hairs. Unlike $P . \times$ vanzhilii, indumentum in $P$. tuvinica is additionally formed by numerous small glandules clearly visible under magnification on petioles and stalks as well as on calyx; nutlets in $P$. tuvinica are smooth.

Below is the determination key for $P . \times$ vanzhilii and its related taxa.

\section{Determination key}

1. Petals obovate or spatulate, $4-5 \mathrm{~mm}$ long ..... 2

+ Petals usually obcordate or orbicular, (6)7-10 $\mathrm{mm}$ long 7

2. Basal leaves pinnate ................... P. multifida

+ Basal leaves ternate or digitate .................... 3

3. Basal leaves digitate (sometimes mixed with ternate and quadruple) ............................................. 4

+ Basal leaves ternate only .............................. 5

4. Leaflets with 5-9 pairs of teeth P. rhipidophylla

+ Leaflets with 2-4 pairs of teeth ...... P. altaica

5. Petioles, stems and calyx with numerous glands P. tuvinica

+ Petioles, stems and calyx eglandular .......... 6

6. Styles at base thickened and papillose ............ P. altaica 
+ Styles at base neither thickened (sometimes slightly thickened) nor papillose ....... P. $\times$ vanzhilii

7. Petioles with straight hairs only

P. arenosa

+ Petioles with crisped-floccose hairs only or with a mixture of crisped straight hairs

8. Petioles with a mixture of crisped (strongly curved-flexuous) and straight hairs. The whole plant or at least sepals distinctly glandular ..... P. evestita

+ Petioles with crisped-floccose hairs only. The whole plant eglandular

9. Terminal leaflet with 3-6(7) pairs of teeth ..... P. nivea

+ Terminal leaflet with 6-12(14) pairs of teeth . P. crebridens

\section{Discussion}

As mentioned above, besides the supposed parental species, three other taxa appear related to $P . \times$ vanzhilii. We believe that $P . \times$ vanzhilii and these taxa are characterized by a common origin, namely, they all share P. multifida as one of the parental species. The small size of leaflets, at least, supports this hypothesis (see determination key). In our opinion, the closest relative of $P . \times$ vanzhilii is P. rhipidophylla which is also restricted to the Khangai region and so far has not been found elsewhere. Soják described $P$. rhipidophylla based on the two findings, by D. A. Klements in 1894 (holotype LE10009660!) and by Ya. I. Prokhanov in 1924 (paratypes - LE10009661!, LE10009662!) in the interfluve of the Tamir and Orkhon rivers in the east- ern Khangai and no further collections are hitherto known. The approximate straight-line distance between the $P$. $\times$ vanzhilii and $P$. rhipidophylla localities is $130 \mathrm{~km}$. Similar to P. rhipidophylla (at least, judging from herbarium materials), morphological characters of specimens of $P . \times$ vanzhilii are stable. Unfortunately, we failed to gather $P$. $\times$ vanzhilii at fruiting stage (in June all plants were at flowering stage). Yet, several plants gathered by E. Ganbold at the end of July had numerous well-formed ripe nutlets. It should be noted that the time interval between Ganbold's and our findings of $P . \times$ vanzhilii is 40 years. All the above facts contribute to the idea that $P . \times$ vanzhilii is the stabilized hybridogenous species represented by two known local populations in the territory of Khangai.

\section{Acknowledgements}

The authors are grateful to the herbaria curators for the opportunity to work with the repository collections, and to I. V. Tatanov for the kindly provided scanned images of type specimens of $P$. rhipidophylla. Special thanks to K. S. Shcherbinin for the illustration of the new taxon. The authors also to thank greatly V. I. Kurbatsky, professor of Tomsk State University, for his helpful advices and assistance and also O. Altangoo, professor and director of the School of Mathematics and Natural Sciences, Mongolian National University of Education, for her support of this research.

This article was prepared with the support of state assignment (project № 6.5498.2017/8.9).

\section{REFERENCES}

Artemov I. A. 2005. New species of Potentilla L. from Western Tuva. Turczaninowia 8(1): 5-10 [In Russian]. (Артемов И. А. Новый вид Potentilla L. из Западной Тувы // Turczaninowia, 2005. Т. 8, вып. 1. С. 5-10).

Grubov V. I. 1982. Opredelitel sosudistykh rasteniy Mongolii [Key for plants of Mongolia (with an atlas)]. Ed. by E. M. Lavrenko. Nauka, St. Petersburg, 443 pp. [In Russian]. (Грубов В. И. Определитель сосудистых растений Монголии (с атласом). Под ред. Е. М. Лавренко. Л.: Наука, 1982. 443 с.).

Peschkova G. A. 1979. Potentilla L. In: Flora Centralnoy Sibiri [Flora of Central Siberia]. Vol. 2. Eds. L. I. Malyshev, G. A. Peschkova. Nauka, Novosibirsk, 554-573 pp. [In Russian]. (Пешкова Г. А. Роtentilla L. - Лапчатка // Флора Центральной Сибири. Т. 2. Под. ред. Л. И. Малышева, Г. А. Пешковой. Новосибирск: Наука, 1979. С. 554-573).

Soják J. 1986. Notes on Potentilla. I. Hybridogenous species derived from intersectional hybrids of sect. $N i$ veae and sect. Multifidae. Botanische Jahrbücher für Systematik, Pflanzengeschichte und Pflanzengeographie 106(2): 145-210.

Soják J. 2009. Potentilla L. (Rosaceae) in the former USSR; second part: comments Notes on Potentilla XXIV. Feddes Repertorium 120(3-4): 185-217. DOI: 10.1002/fedr.200911102

Soják J. 2012. Potentilla L. (Rosaceae) and related genera in Asia (excluding the former USSR), Africa and New Guinea. Notes on Potentilla XXVIII. Plant Diversity and Evolution 130(1-2): 7-157. DOI: 10.1127/18696155/2012/0130-0060 